$45(2) \mid 2016$

Varia

Lima, 25, 26 y 27 de mayo de 2016

Taller de Escáner 3D

Lima, 25, 26 y 27 de mayo de 2016

\title{
Quentin Marchand
}

\section{OpenEdition}

Journals

Edición electrónica

URL: http://journals.openedition.org/bifea/8027

DOI: $10.4000 /$ bifea. 8027

ISSN: 2076-5827

Editor

Institut Français d'Études Andines

Edición impresa

Fecha de publicación: 1 agosto 2016

Paginación: 355-356

ISSN: 0303-7495

Referencia electrónica

Quentin Marchand, «Taller de Escáner 3D », Bulletin de l'Institut français d'études andines [En línea], 45

(2) | 2016, Publicado el 08 agosto 2016, consultado el 07 noviembre 2020. URL : http://

journals.openedition.org/bifea/8027 ; DOI : https://doi.org/10.4000/bifea.8027

\section{(c) (i) (9)}

Les contenus du Bulletin de l'Institut français d'études andines sont mis à disposition selon les termes de la licence Creative Commons Attribution - Pas d'Utilisation Commerciale - Pas de Modification 4.0 International. 
Événements

\section{TALLER DE ESCÁNER 3D}

Lima, 25, 26 y 27 de mayo de 2016

El 25, 26 y 27 de mayo de 2016, se realizó el primer taller de Escáner 3D, organizado por el Instituto Francés de Estudios Andinos y el Ministerio de Cultura del Perú y del Museo de Sitio de Pachacamac.

Este evento se realizó con la colaboración de Christophe Moulhérat, encargado del análisis de las colecciones del Museo Quai Branly (París, Francia). Hace 6 años que los especialistas del museo empezaron a utilizar las técnicas de los escaneres medicales y de la impression 3D para revelar los secretos de los objetos de su colección.

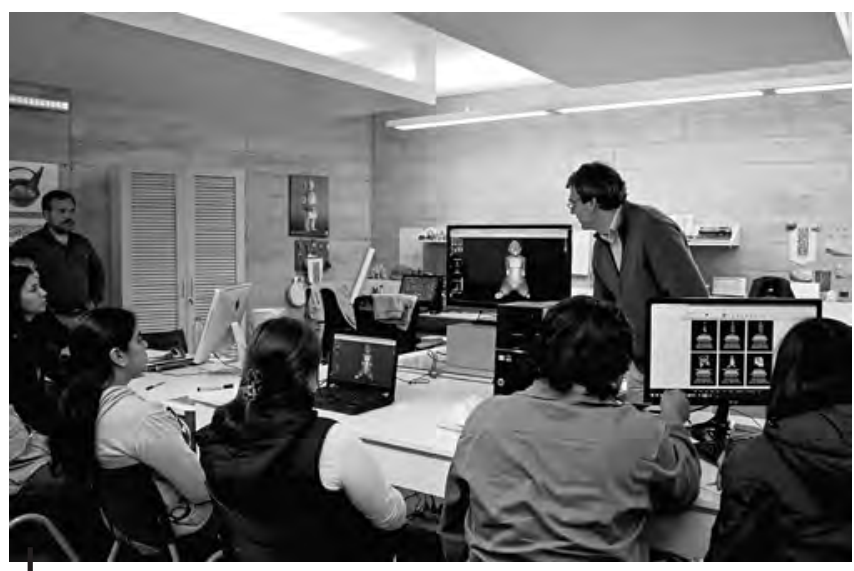

Presentación del programa por Christophe Moulhérat

(c) Kattia Pacheco
El taller tuvo como objetivo principal presentar y transmitir este conocimiento técnico acerca de las tecnologías de tratamiento de imágenes (mediante el programa Vizua) y de digitalización 3D (mediante el uso del escáner 3D, escáner rayón X estándar, Cone Beam e industrial). Estas tecnologías tienen la ventaja de no necesitar un material costoso, y se pueden usar de manera sencilla, dando más libertad y posibilidades de trabajo a los investigadores y responsables de museos.

El taller se orientó justamente hacia profesionales con experiencia en el campo de la restauración y conservación de objetos arqueológicos. El objetivo era también abrir el taller al personal de varios sitios arqueológicos del Perú para que estas técnicas se difundan al nivel nacional.

El taller empezó en el nuevo Museo de sitio de Pachacamac, con una presentación magistral de las técnicas de escaneo y del proceso de traslado, manipulación y cuidado de las piezas arqueológicas del museo hasta el hospital. A partir de la tarde, los participantes venidos de ocho sitios arqueológicos del Perú empezaron ya los trabajos prácticos. Trabajando en grupo empezaron a manipular los objetos escaneados del Museo Quai Branly a partir de la plataforma virtual.

El segundo día, en el IFEA, los participantes continuaron a familiarizarse con la utilización de este programa, realizando fotos 3D y grabaciones videos de los elementos revelados por manipulación de los objetos escaneados. El Dr. Moulhérat presentó también objetos impresos en 3D a partir de los escaneos: a partir de estos objetos impresos en escala real, se puede suponer el tipo de material y cómo fueron fabricados. 


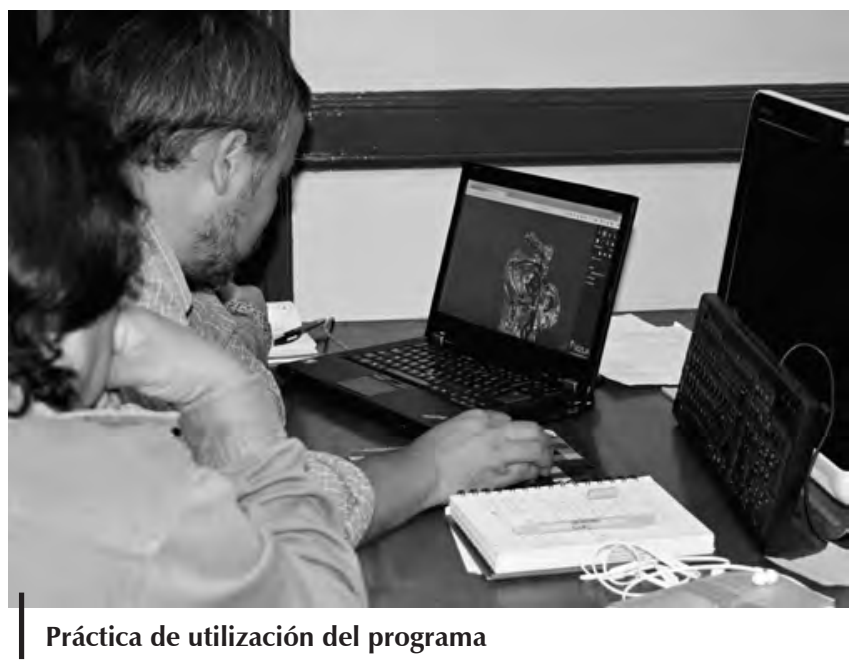

(C) Kattia Pacheco

El ultimo día, los participantes al taller recibieron la visita de dos especialistas del Ministerio de Cultura que estaban interesados en conocer los alcances de esta técnica. Finalmente, el taller se cerró con una charla sobre las futuras aplicaciones de estas técnicas en el ámbito de la arqueología peruana. Estas técnicas novedosas abren nuevas posibilidades tanto en la investigación como en la museología. Ahora, el desafío consiste en vincular varios actores tanto del sector de la salud para realizar los escaneos de momias como del sector del patrimonio y de la cultura para almacenar los objetos escaneados en una plataforma virtual colaborativa.

Quentin Marchand

Voluntario Internacional, IFEA

Doctorando en Geografía de Paris I Panthéon-Sorbonne 